\title{
Pneumoperitoneum from acute gastric dilation and perforation
}

\author{
Fernando Azevedo, ${ }^{1,2}$ Carolina Canhoto, ${ }^{1,2}$ Beatriz Costa, ${ }^{1,2}$ Hélder Carvalho ${ }^{1,2}$
}

${ }^{1}$ General Surgery, Hospital and University Centre of Coimbra, Coimbra, Portugal

${ }^{2}$ Faculty of Medicine, University of Coimbra, Coimbra, Portugal

\section{Correspondence to}

Dr Fernando Azevedo; fjcr.azevedo@gmail.com

Accepted 7 November 2019

\section{DESCRIPTION}

Acute gastric dilation with perforation is a rare clinical entity whose aetiology is not completely understood. ${ }^{1}$ This problem may occur secondary to trauma, diabetes mellitus, electrolyte disturbances, gastric volvulus, infection, psychiatric or eating disorders, or in the immediate postoperative period. This condition requires a high index of suspicion that enables early diagnosis and treatment. ${ }^{23}$

We present a case of a 48-year-old woman who presented to the emergency department with complaints of diffuse abdominal pain and vomiting for 1 day. The patient had a history of ulcerative colitis with uveitis and arthritis, well controlled with immunotherapy.

At physical examination, the patient was without fever, haemodynamically stable, with diffuse abdominal pain with contracture and rebound tenderness. The X-ray showed pneumoperitoneum and massive gastric dilation (figure 1).

An exploratory laparotomy was performed, revealing acute gastric dilation, with multiple longitudinal lacerations in the small curvature and areas with necrosis and perforation up to the subcardic area (figure 2). No obstructive bowel or gastric lesions were found. The patient underwent a total gastrectomy with stapled Roux-en-Y anastomosis. She was discharged on the 12th postoperative day, without complications. Histological examination

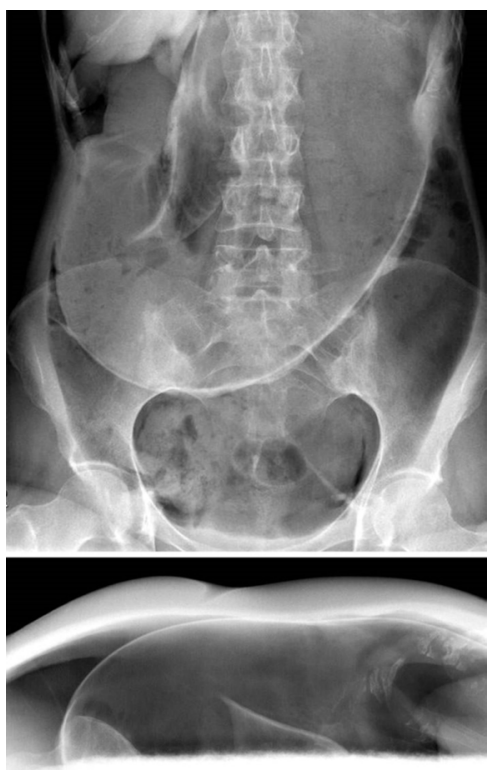

Figure 1 Abdomen X-ray showing pneumoperitoneum and massive gastric dilation.

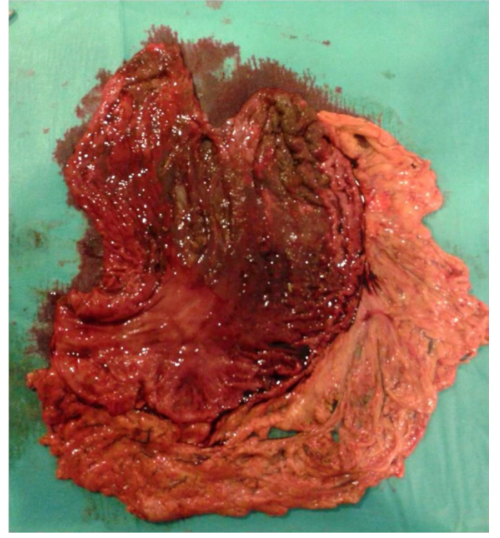

Figure 2 Surgical specimen revealing areas of necrosis and perforation.

confirmed the prior diagnosis. At 3 years of follow-up, the patient is asymptomatic.

Acute gastric dilation is a rare condition with potentially lethal consequences. Early diagnosis and prompt surgical treatment are essential in the management of the patient. The presence of immunosuppression, like it was described in this case, may delay diagnosis due to the absence of early symptoms.

\section{Learning points}

Acute massive gastric dilation is a rare disease with poorly understood aetiology.

- A high index of suspicion is important, which enables early diagnosis and treatment, minimising the morbidity and mortality caused by this entity.

- Surgical therapy with resection is mandatory in this condition.

Contributors FA and CC collected the data, performed the literature search and wrote the manuscript. BC collected the data and reviewed the manuscript. $\mathrm{HC}$ reviewed the final version of the manuscript.

Funding The authors have not declared a specific grant for this research from any funding agency in the public, commercial or not-for-profit sectors.

Competing interests None declared.

Patient consent for publication Obtained.

Provenance and peer review Not commissioned; externally peer reviewed.

\section{REFERENCES}

1 Todd SR, Marshall GT, Tyroch AH. Acute gastric dilatation revisited. Am Surg 2000;66:709-10. 
2 Turan $\mathrm{M}$, Sen M, Canbay E, et al. Gastric necrosis and perforation caused by acute gastric dilatation: report of a case. Surg Today 2003;33:302-4.
3 Steen S, Lamont J, Petrey L. Acute gastric dilation and ischemia secondary to small bowel obstruction. Proc 2008;21:15-17.

Copyright 2019 BMJ Publishing Group. All rights reserved. For permission to reuse any of this content visit

https://www.bmj.com/company/products-services/rights-and-licensing/permissions/

BMJ Case Report Fellows may re-use this article for personal use and teaching without any further permission.

Become a Fellow of BMJ Case Reports today and you can:

- Submit as many cases as you like

- Enjoy fast sympathetic peer review and rapid publication of accepted articles

- Access all the published articles

Re-use any of the published material for personal use and teaching without further permission

Customer Service

If you have any further queries about your subscription, please contact our customer services team on +44 (0) 2071111105 or via email at support@bmj.com.

Visit casereports.bmj.com for more articles like this and to become a Fellow 